UDC 622.647 .5 .01

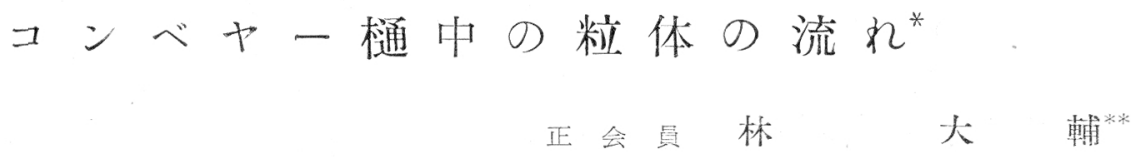

\title{
Flow of Granular Fluid on Conveyer-Trough
}

Daisuke HAYASHI

The author summes up his research on the effects of internal frictional-resistance on the chain-pull of the perforated conveyer-trough by means of measuring its dynamic side wall pressure and the flow patterns of the conveyed materials (beach gravels).

The results obtained are as follows:-

1) The weaker the scraping action of the chain and the stronger the side wall frictional coefficient, the greater becomes the structural-variation-resistance based on the mutual slips of conveyed granular fuid materials.

2) Accordingly, the structural-variation-resistance keeps the close relationship with the flow-patterns of the conveyed fluid materials.

3) The greater the structural-variation-resistance, the greater becomes the dynamic pressure on the side wall.

4) When the granular fluid materials with the same size are used, under the same heightwidth ratio, the narrower the trough-width, in the greater ratio becomes the structural-variation-resistance.

\section{1。緒言}

特別の搔板を持たす樋の高さに比較して背の低い千ェ ーソを使用するチェーン・コンベーの類は, 至極簡临 な構造のるのですことは雕知の通りであるが，簡単な 割合にこの樋の!の運搬䊁体の流れとチェーンの率引抵 抗との関係についてはなだとれ程詳細でない。

著者はごく短かい樋を便つた模型的な洼置でも垁験の 万法さえ考慮すれば, 長い榑の場合と同様の結果を推察 するに是るデータが計測され，以上の関䋆が簡健に榷め られること老知つ无のだ，二三の場命について実験的な

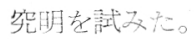

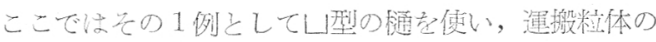

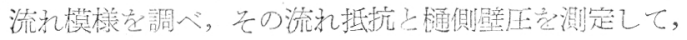
粒体間の相互滑り飞よる流㧈抵抗力存在するニとと，そ の発現度合が同一種類で同一粒度の粒体でる，その積高 さや樋とチェーンの相対寸法等の相違によつて著しく違 つてくることを証明してパーホレーテッド・ベルトを使 つた嗵コンベャーの設計資料の一端とする。

\section{2. 裝置上方法}

\section{$2 \cdot 1$ 裝置の I}

* 昭和 32 年 2 月1 日受理

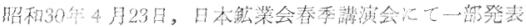

** 虗児息大学工学部教授
粒体の樋印での流れ模様を上表面から観察することは 容易であるが，この上表面流れと内部の動き之の関連は 直接内部が見劣ないと詳細をつくす訳にゆかない。

この意味で第 1 図の上らに長さ $20 \mathrm{~cm}$ 程の木樋の底に 曳板を固き,この上にガラスや竹の細棒を䅡又, 曳板を移 動乙て棒端の流れ模様を計測する装置とすると，運搬物

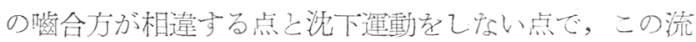
れ模梯は粒体の流れともちろ九同一のものではないが， 㫣板の移動が僅少で粒体の沈下運動が微量の場合とは上 く似た傾向者示しているので，この装置によつて板面の 摩擦係数や樋布設角・壁面傾斜危去の他の条件の相違に よる上表面流れと内部の動きの関連を詳細に考察されて 便利である。

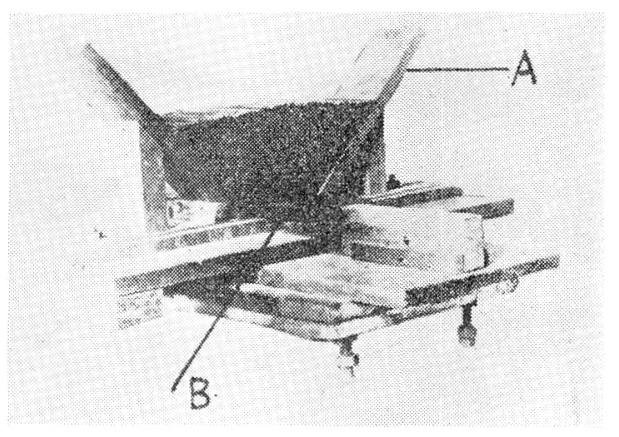

第 1 図 


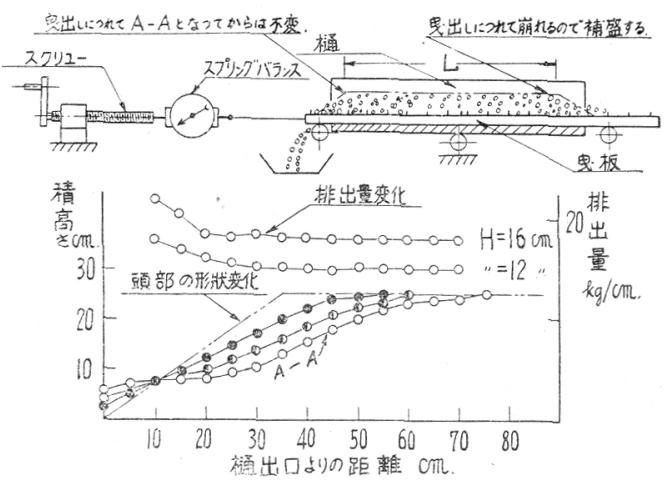

第 2 図装置II 測定方法

\section{$2 \cdot 2$ 裝 置 $の$ II}

装置のIと同じ型式ではあるが，運般物として粒体を

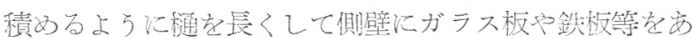
てるようにしたりチェーンとして平板の外に解栈つき

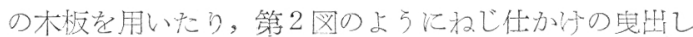
装置を用意して家出乙速度を $0.03 \mathrm{~m} / \mathrm{sec}$ 亿保つようにし たり，スプリングバランスで卒引抵抗者計るようにした 等の点で違つている。

な拉，この装置笑用機の檤やチェーンを用いても一

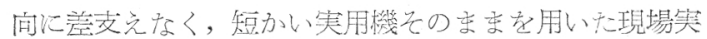
験も著者は実施している(別に報告している)が，ここ では慔型実験としての利用価值を示すためを社等には触 れない。

樋の長さ：樋の長さは短かい程粒体も少量でする，帮 験操作も簡単で万事手軽にすす党がやはり限度がある。 樋の最短長は，樋の中に粒体を積及气の上面を均ら乙， この面汇適当な間隔で石爽粉等で横断白線を描いた上で チェーンを移動する上第3図のよ5に白線の変形が起 り，この変形模様が樋の頭・尾・胴の各部でそれ旮れ違 うので，この相違を利用して頙尾部が判然と区別出来る ように相当な長さをるつた胴部を与光る上らに樋の全長

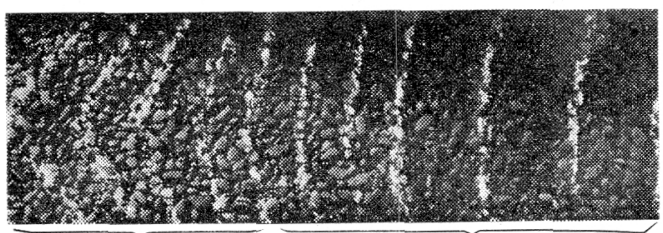

頙 部

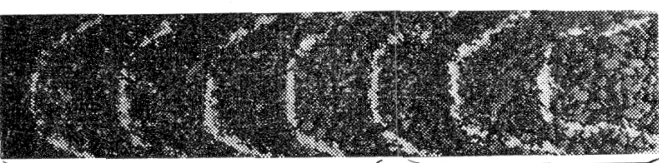

尾部

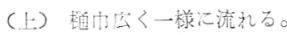
(下) 捕门㷋く流れにくい

第 3 図 粒体の上表面流れ分布曲線
を決定する。こうして決定した樋の全長は側壁の角度や 樋の布設角, 底巾等で違つて来る。

著者がし型递でヴ 8 20cmのもの老水平布設とした 場合江使用した樋長は $2 \mathrm{~m}$ である。

\section{$2 \cdot 3$ 流れ量と流れ抵抗の測定}

粒体の流れ量二頭部からの排出量の求め方：この求

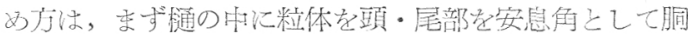

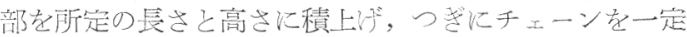
速度で兒出しながら，或出乙単位長さ当りの排出重量を 計測してゆくと，最初は第２四の上5亿頭部分余分に崩 れるためこの排出量は多いが，㫣出しにつれて崩れる量 が漸次滅りじきに一定值に落ついて，一定の形状をした 頭部となつてくるので, 胴・尾部は補盛りをしながらこ

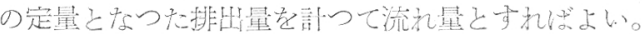

流れ係数： 粒体は特定条件の場合圭除いては，千. ーンと同速度で全部均一に流れる恠でないので，チェー ンと同速度で全部の粒体が均一に流れると仮定した場合 の排出量と笑際排出量との比をとつて流れ係数とした。

流れ抵抗：以上の操作に上つて頭部の稹又具合を落 ちつか子た上で補盛りして，所定の高さと長さをした胴

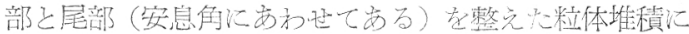
ついて，チェーン整引加をスフリングル゙ランスで第1に 計り，つぎにこの場合に形成したと同様な堆積から胴部 分だけを除去したるのを別につくり，これについてのチ ェーン算引门大第 2 亿求め, さらに以上の胴部の粒体堆

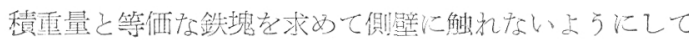

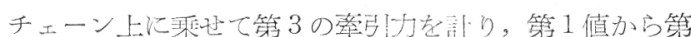
2 值と第3 值の合部美引几て, この值をもつて流机担 扰の比輘值とした。

\section{$2 \cdot 4$ 樋內部の粒体の流れ模樣の観測}

粒体の示す内部の流れ模様の大体の傾问は装置 I 用すると容易飞推察されるが，運搬物の相遠から詳細の

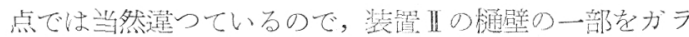
又張りと乙て着色粒体の流れ癷追跡したり，粒体磁山に 水平に細棒を並べ挿人してその外端の動さを澌㯰したり する等の方法で具体的汇陮めた。

\section{$2 \cdot 5$ 側壁圧の測定}

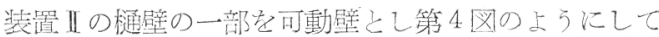
下方を蝶番とし上端の変位を $0.5 \mathrm{~mm}$ ヒする1〉ようにダ イヤル・ダージで拥党バネの動き堂監視しながら，桩大 レバーを使つて側壁圧をダイヤフラム・ケージに移し， 望遠鏡でマノメーターを続妏つて, 粒体の踭止時之移動

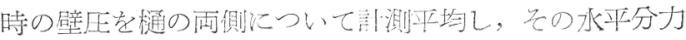
$E$ を求めた。

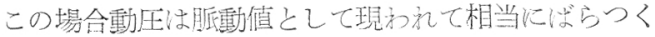
ので，各值は測值20回の平均值で离る。 


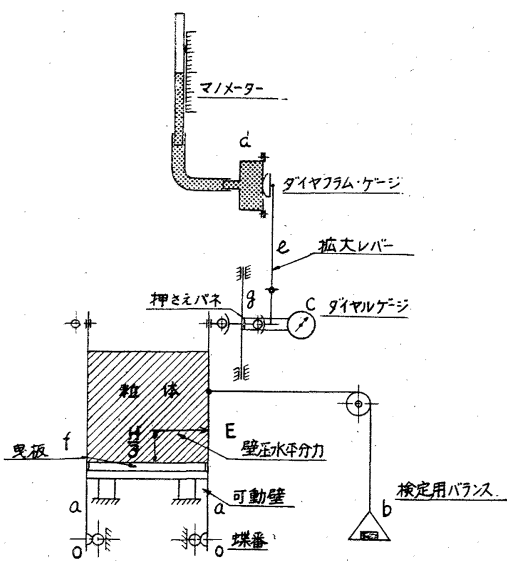

第 4 図

側壁圧測定 装置

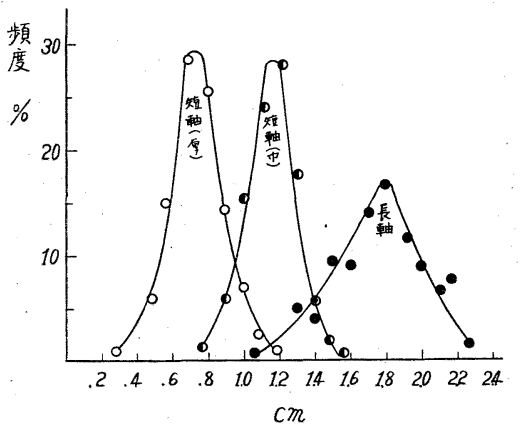

第 5 図 砂利 $\mathrm{G}_{1}$ の軸 長頻度

\section{第 1 表}

\begin{tabular}{|c|c|c|c|c|c|c|c|c|c|c|}
\hline \multirow{2}{*}{ 崜别 } & \multirow{2}{*}{ 符号 } & \multirow{2}{*}{ 軸 } & \multirow{2}{*}{ 長 } & \multirow{2}{*}{ 比 } & \multirow{2}{*}{$\begin{array}{l}\text { 等価 } \\
\text { 直 } \\
\text { 径 }\end{array}$} & \multicolumn{2}{|l|}{ 比 } & \multicolumn{2}{|c|}{ 摩擦角 } & \multirow{2}{*}{ 安定角 } \\
\hline & & & & & & 真比重 & 見掛 & 側板 & 曳板 & \\
\hline 砂 & $\mathrm{G}_{1}$ & $17.90=$ & 11.40 & $=7.40$ & 11.50 & 2.65 & $\begin{array}{l}1.65 \\
\sim 1.70\end{array}$ & $23^{\circ} 18$ & $35^{\circ} 00^{\prime}$ & $40^{\circ} 00^{\prime}$ \\
\hline 利 & $\begin{array}{l}\mathrm{G}_{2} \\
\mathrm{G}_{3}\end{array}$ & $\begin{array}{l}8.90: \\
1.19:\end{array}$ & $\begin{array}{l}5.77 \\
0.87\end{array}$ & $\begin{array}{l}: 3.46 \\
: 0.70\end{array}$ & $\begin{array}{l}5.69 \\
0.89\end{array}$ & $\begin{array}{l}2.97 \\
2.74\end{array}$ & $\begin{array}{l}1.53 \\
1.43\end{array}$ & $\begin{array}{l}28^{\circ} 00 \\
3^{\circ} 40^{\prime}\end{array}$ & $\left|\begin{array}{ll}36^{\circ} & 00^{\prime} \\
35^{\circ} & 40^{\prime}\end{array}\right|$ & $\begin{array}{l}39^{\circ} 00^{\prime} \\
34^{\circ} 20^{\prime}\end{array}$ \\
\hline 石 & $C_{1}$ & $14.37:$ & $9.60:$ & : 6.39 & 9.59 & 1.65 & $\begin{array}{l}0.77 \\
\sim 0.80\end{array}$ & $28^{\circ} 10^{\prime}$ & $31^{\circ} 30^{\prime}$ & $41^{\circ} 40^{\prime}$ \\
\hline 炭 & $\begin{array}{l}\mathrm{C}_{2} \\
\mathrm{C}_{3}\end{array}$ & $\begin{array}{l}8.95: \\
5.48\end{array}$ & $\begin{array}{l}5.33 \\
3.88\end{array}$ & $\begin{array}{l}3.51 \\
2.31\end{array}$ & $\begin{array}{l}5.56 \\
3.36\end{array}$ & $\begin{array}{l}1.65 \\
1.70\end{array}$ & $\begin{array}{l}0.77 \\
0.80\end{array}$ & $\left\{\begin{array}{l}27^{\circ} 30^{\prime} \\
27^{\circ} 10^{\prime}\end{array}\right.$ & $\mid \begin{array}{l}30^{\circ} 25^{\prime} \\
35^{\circ} 55^{\prime}\end{array}$ & $\begin{array}{l}44^{\circ} 00^{\prime} \\
41^{\circ} 40^{\prime}\end{array}$ \\
\hline
\end{tabular}

りの木板で静摩擦係数 0.43 のものを利用し，砂利 $\mathrm{G}_{1}$ を 運搬粒体とした場合, 積高さ $H$, 樋巾 $B$ と関係する流れ 係数 $\eta=G_{l} / B \cdot H \cdot l \cdot \gamma \ldots \ldots\left(G_{l}\right.$ は排出重量, $l$ はチェ一

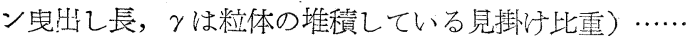
と，このGてを排出する場合の流れ抵抗 $F$ と，この $F$ に基 ずいて計算した積込胴部単位重量当りの抵抗值 $F / B \cdot H$. $L \cdot \gamma \cdots \cdots(L$ は胴部長 $) \cdots \cdots \cdot$ の值を第 6 圀に，上と同一側 壁板で曳板のみを平板に $1.5 \mathrm{~cm}$ 角材を $8 \mathrm{~cm}$ 閒隔で横に 栈づけたるのに取換えた場合と，电板は変光ず側壁の みを静摩擦係数 0.28 のガラス板に取舆劣た場合とを別に 加光，流れ抵抗を実蔡の流れ量単位重量当りとした $F$ $G_{L} \cdots \cdots\left(G_{L}=B \cdot H \cdot L \cdot \gamma \cdot \eta\right) \cdots \cdots$ で表わした例を第7図 に示す。

\section{$3 \cdot 2$ 流れ模樣}

上表面の粒体の流れ模様は第3 図の通りであるので, この表面の流れ分布と内部の動きとの関連を求めると第 8 図の例示となる。図の下右榬高さの低い場合, 下左 は高い場合で，上図は積高さの増加に伴なう上表面流れ と○○点の位置にそれぞれ相当する縱断面内の流れ速度 の変化を示するので，積高さが増すとともに粒体の流れ は均一を欠き相互間に滑りを生し，上表面・縦断面のそ れぞれの流れ分布曲線は漸次屈曲の度合を増して流れ係 数 $\eta$ の減少を来たし，ある積高さを越えると曳板に近接 する粒体層のみ流れて，上層は全体として流れは停滞し て上表面の流れ分布曲線をかえつて平滑化し，縱断面の 流れ曲線を局部において著しく屈曲させて来ることが理 解される。

第 9 図は装置Iによつて求めた積高さと $\eta$ 曲線の求め 方とその結果の一例であり(側壁角をむつた場合)，第 6 図の $\eta$ 曲線には示してない上うな積過ぎによる 減現象を破線によつて提示したものである（第8困の下 左闵のようになるとこの急減現象を示す)。

\section{$2 \cdot 6$ 粒 体試 料}

粒体と乙ては楕円形の海岸砂利 $\mathrm{G}_{1}$ を 洗浄乾燥乙て主用乙, 補助と乙て相似形 の小砂利 $\mathrm{G}_{2} \cdot \mathrm{G}_{3}$ と, 有煙炭塊の相似形 である $\mathrm{C}_{1} \cdot \mathrm{C}_{2} \cdot \mathrm{C}_{3}$ を用いた。

試料の諸元を第 1 表に， $\mathrm{G}_{1}$ の 5000 個 についての長短各軸長の頻度を第 5 図に 例示する。

\section{3. 実 験の 結 果}

\section{$3 \cdot 1$ 流れ係数と流れ抵抗}

装置IIでチェーン代用の曳板として桶巾 と同一ウで荒削りした平木板で静摩擦係 数 0.70 のすのを, 樋側壁として仕上げ削

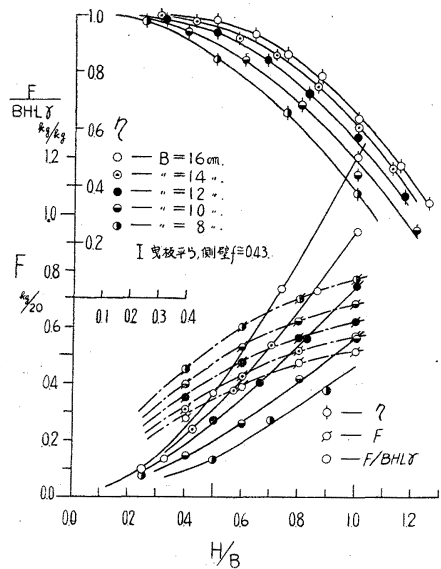

第 6 図 流れ係数之積込単位重量 当りの流れ抵抗

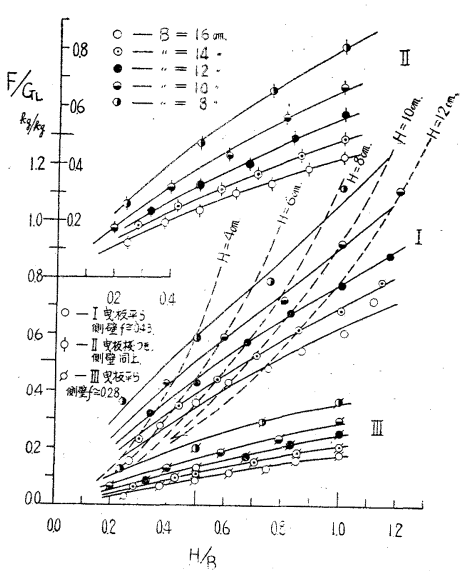

第 7 図、些流れ量単位重量当 りの流れ抵抗 

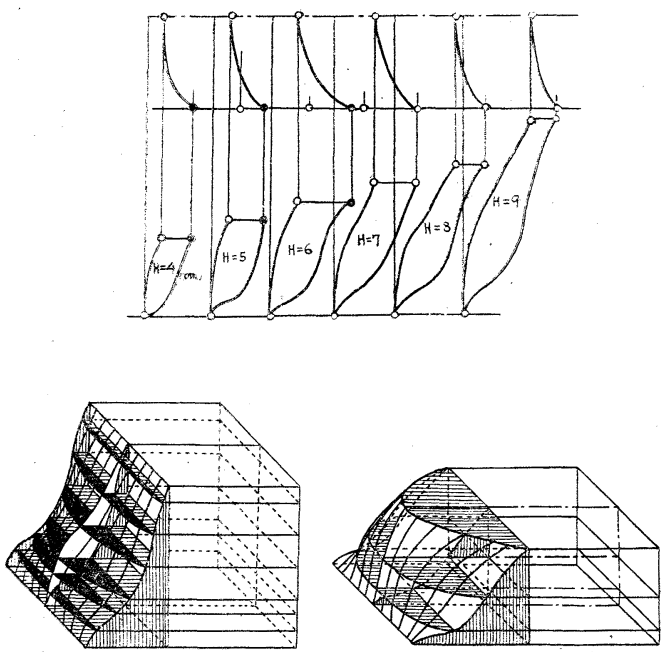

第 8 図流孔模样

ともあれ，この流れ模㥞によつて上表面の流れと内部 の動さとほ一定の関連があり，チェーンの搔出乙作用が 粒体の嚙合を通しててく伝達される程, 側壁が滑らかで 流れを引止わない程，この関連が単純になり，とくに積 高さの低い場合には縦断面内の流れ分布曲線を直線とみ な乙て大差ないことが推察される。

この推察そ確実にするため，側壁の摩擦㐿数が 0.43で 曳板が平板の場合と栈つきの場合のそれぞれについて， 流れ係数 $\eta$ 之上表面の平均流れ率。 $l_{m} / l$ との関係を求める と第10図となつて，棧つきでチェーンの搔出し作用がよ く伝達される程側壁摩擦の小さい程 (困示は省略) 積高 さの低い程, 両比率は近似し, 乙かも $\left(1+l_{m} / l\right) \cdot \frac{1}{2} \div \eta$ $=1$ の線（表面速度と内部速度とは直線関係にあると言 万意味）に沿つて来る。

\section{$3 \cdot 3$ 上表面流れ分布曲線の尖りと粒体の㨭れ}

上表面の粒体の流孔之内部の動きに上述のよ5な簡単 な関係が岁る場合には，上表面の流れ模様を見ただけで 内部の動き学決定出来るので実技での観測に応用して都
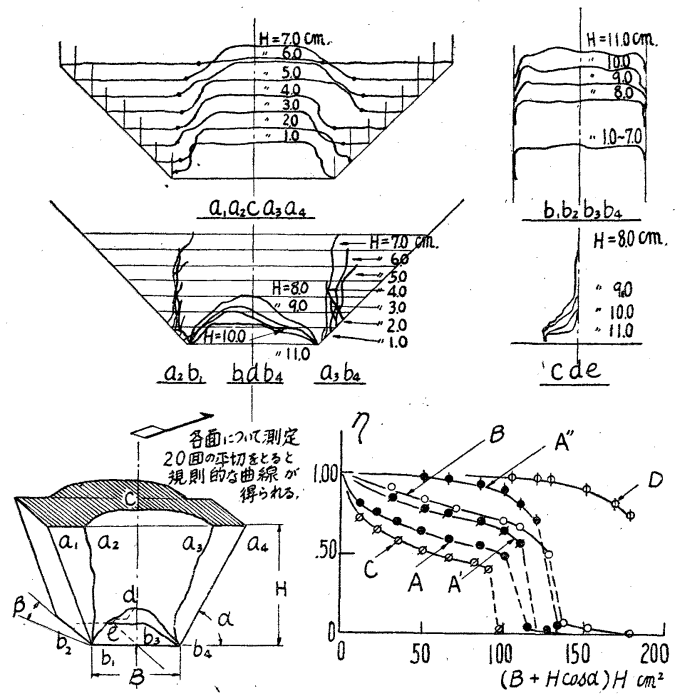

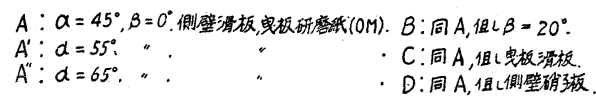

第 9 図装置 Iによる流れ模椂と流れ係数の例示

合がよい。

この意味で上表面の流れをさらに精査して流れ分布曲 線の尖り方 $(d l / B \cdots \cdots d l$ は樋中央の流れの最大值) を求 めて見ると第11図となつて, 同一の比積高さ $H / B$ では 樋巾の狭い方がよく尖り, 同一の桶巾では積高さが増加 する程よく尖り，限界積高さで尖り方が極大となり，以 後は逆に㺂少する傾问となつている。

この尖り方が激しいだけそれだけ粒体相互間に滑りを 生じて和り, 滑るにつれて新しい嚙合を構成して, 粒体 に振り回転運動を発生していることが認められる。

上表面の粒体は上方が自由面であり内部の粒体より運 動の自由度が大きいので, この上表面の流体の動きで内 部のそれを同一として律することは出来ないが，類推さ れることは確かなので, 着色粒体を表層に埋めてその軸 線が相互滑りによつて捩られて回転する角度を, 蛹巾の

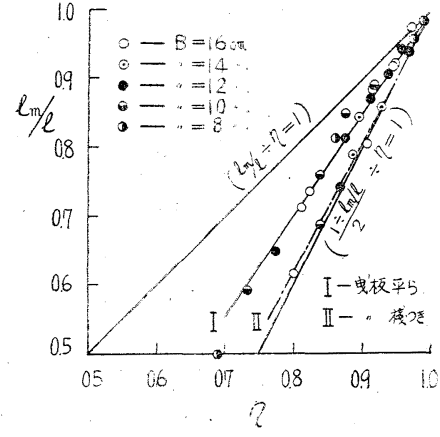

第10図 表面流れ分布と流れ倸数

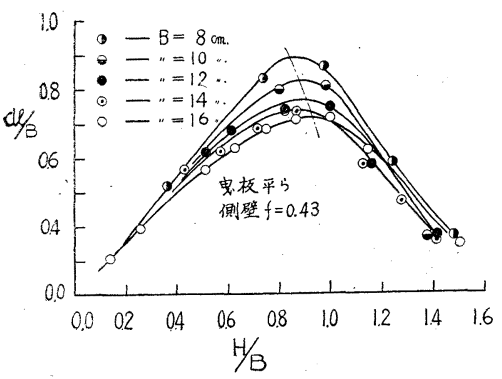

第11図 流れ分布曲線の尖り

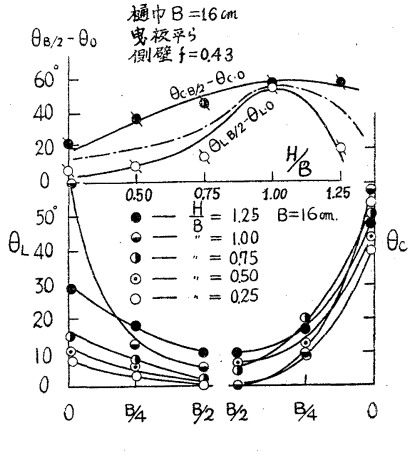

第12図 粒体の回転角度 


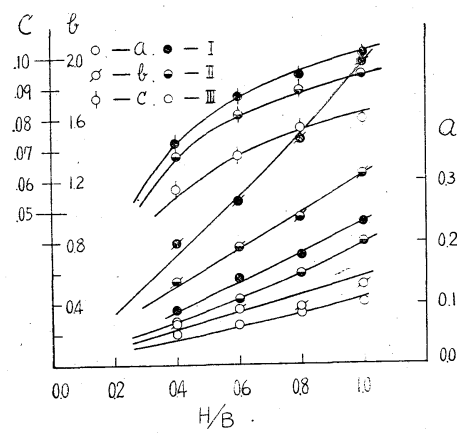

左 第13図 流れ抵抗の係数值

右 第14図 側壁の動・静圧

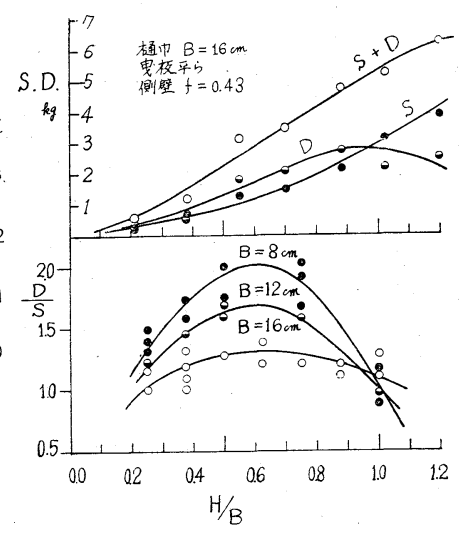

結局内外摩擦力を考慮の゙れば足りる。 粒体群が流れるにしたがつてその内 部で相互に滑るとすると，滑るために は粒体群の啮合構造が変化する必要が あり,この構造変化の結果として粒体 の捱れや傾斜運動を生ずる。

粒体に换れ傾斜運動が強制されると その結果の一つとして流れ方向に直角 な圧力を発生する2)3’4)。

筩の十の粒㑂では上表面は自由面な ので, 浅層のもの程上方への転動が容 易であり，側壁への横圧力の発生はそ れだけ弱められている可能性があるが

$16 \mathrm{~cm}$ の場合について計測して例示すると第 12 図とな り，積高さの増加につれて捩られる度合の変化する傾向 は第11図とほぼ一致している。図で $\theta_{L}$ は長軸線を樋軸 と平行に， $\theta_{C}$ は長軸線を桶軸に直角に置いた場合の回 転角であり， $\theta_{B / 2}-\theta_{0}$ は樋巾の中央と側壁面で示すとれ ぞれの回転角の差額であり，-・・・線はこの差額の軸方向 別のものの平均である。

\section{$3 \cdot 4$ 側 壁 圧}

流れ模様と流れ抵抗とをあつと具体的に相関させるた めには側壁圧の測定結果によると便利である。

第 7 図に例示した樋巾・積高さ・流孔抵抗の関係を実 験の範国でまとめると，

$$
F / G_{L}=a+b e^{-\boldsymbol{c B}}
$$

となつて, 熥巾の絶対值 $B$ を含まない初項と， $B$ を含む 次項とに分けて整理され， $a \cdot b \cdot c$ の各係数は $H / B$ の 関数として第13図に示される。

このことは流れ抵抗が，粒体の流れ模様に関係せず， 樋巾・積高さについて相似則の適用される部分と, そ5 でない部分とから構成されることを意味するようなので 粒体群の静止時と移動時の側壁圧 $S$ と $D$ を計り，D/Sを 求めると第14図の例示となつて, 積高さにしたがつて増 加する静側壁圧の外に, 粒体の動きに相応して増減し樋 巾と逆比する動側壁圧の存在が確認される。

な特この動側壁圧中には粒体の動きによる振動や沈下 によるものが付加されて現われていることも当然考劣ら れるが, 同一の比積高さ $H / B$ では随巾の狭い方, 言いか 旮ば積高さの低い方ががつて動圧が大きいことで, その量は存在しても僅少であることに閒違いなく, 事実 激しく振動して見ても図に示す傾向を逆にする程の影響 はもつていないので，とくに区別して算定しなかつた。

\section{4. 考察}

この実験に使つた砂利のような粒体では，流れに対す る抵抗因子として凝集・粘着の両力は無視してよいので
既揭の結果では比積高さが同一でも実際の積高さが低く て樋巾の狭い方がより確実に動側壁压の存在を示し, 静 側壁圧に対する割合も多くなつており，棈造変化抵抗が 流れ抵抗の主要部分を占めていることを例記しているの で，横圧力の発生が以上の可能性によつて目立つ程弱め られていないことを示している。

この横圧力の発生と結びついた構造変化抵抗を認めて 初めて, 動側壁圧の变化と流体の流れ模様とがよく相関 している事実や，樋巾や曳板の性状寸法が流れ模様—— 進んでは流れ抵抗に強く影響している理由が説明される と考える。

試みに砂利 $\mathrm{G}_{1}$ の崩壤角 $\alpha$ を $69^{\circ}$ 前後と仮定し ${ }^{5)}$, ク一 ロン土圧論にしたがつて静側壁圧の水平分力 $E$ を略算す ると，比積高さ $H / B \cong 1$ 以下では両側壁面について

$$
\begin{aligned}
E & =2 \cdot G_{w} \cdot \frac{\sin (\alpha-\varphi) \cos \beta}{\cos (\alpha-\beta-\varphi)} \\
& =2 \cdot G_{w} \cdot \frac{\sin \left(60^{\circ}-40^{\circ}\right) \cos \left(13^{\circ} \sim 20^{\circ}\right)}{\cos \left[60^{\circ}-\left(13^{\circ} \sim 20^{\circ}\right)-40^{\circ}\right]} \\
& \cong 0.74 \cdot G_{w}=0.42 \cdot W \frac{H}{B}
\end{aligned}
$$

となる。ただし $G_{w}=$ 粒体楔重量, $W=$ 積込粒体重量, $\phi=$ 粒体の内部摩擦角で安息角に等しいとした值， $\beta=$ $90^{\circ}+\delta^{\prime}-\theta$ で $\delta^{\prime}=\left(\frac{3}{4} \sim \frac{1}{2}\right) \rho, \theta=$ 壁面の水平となす 角。

この静側壁による実際の流れ粒体単位量当りの流れ抵 抗は $0.42 \cdot \frac{H}{B} \cdot \frac{f}{\eta} \cdots \cdots(f$ は側壁摩擦係数 $) \cdots \cdots$ となる。

クーロン土圧論による算式はその性質上略值しか与兄 ないが，一応の目安をつけるには使える。

上式に既知の $f$ や $\eta$ 代大して得た結果と $F / G_{L}=a+$ $b e^{-\boldsymbol{c B}}$ 式の $a$ 值とを比較すると，ほぼ近似しているので この $a$ を静側壁圧による摩擦抵抗值と見て大差ないこと となり, 結果としてb $e^{-\boldsymbol{c B}}$ が別の原因, すなわち動側壁 圧として現れた粒体群の相互滑りによる摩擦抵抗に相当 するとして推定してよい。 


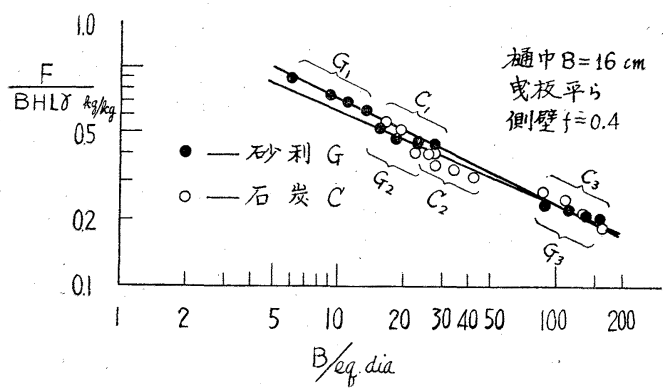

第15図 等価直径と積込量単位当りの流れ抵抗

以上の両種の抵抗比を実験の範囲で $H / B \leqq 1$ の場合に ついて求めると,

$$
\frac{7.8 \cdot f^{2} \cdot\left(\frac{H}{B}\right) e^{-f\left(\frac{H}{B}\right)^{0.253} \cdot B}}{0.42 \cdot\left(\frac{H}{B}\right) \cdot f}=K \cdot f \cdot e^{-f\left(\frac{H}{B}\right)^{0.253} \cdot B}
$$

となる。この式でKは粒体の内部摩擦角とチェーンの性 状による係数である。

\section{5. 既知の報告との関連}

既知の報告では，側壁の静圧に触れ ${ }^{6)}$ ，この静圧に基 ずいたチェーン㐮引力を算定し ${ }^{788)}$ ，粒体の大きさと流 れ抵抗との関係に論及し ${ }^{9)}$, さらに進んで粒体の種類や 大きさとチェーン・樋の形状・寸法との関係から本報告 の流れ係数と同樣な係数を提示しているが，動側壁圧を

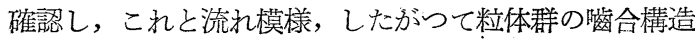
の変化による抵抗との結びつけをしているるのは見受け ない。

な特実際上コンベヤーの設計と使用条件の選定にあた つては，粒体が一様に流れるように務めて，この構造変 化抵抗をなるべく排除するのが建前であり，この建前を 守つて運転されているものにとつてはこの抵抗は当然僅 少值であるので，無視されても善支えなく，このような 場合も多いと考える。

\section{6. 実験結果の普遍性}

既揭の実験は粒体として砂利 $\mathrm{G}_{1}$ のみを使用しているの で普遍性に乏しいので，この $\mathrm{G}_{1}$ と形状が注ぼ相似し，粒 度線もよく似ている小粒の砂利の $\mathrm{G}_{2} \cdot \mathrm{G}_{3}$ と同様の選択 をした石炭 $\mathrm{C}_{1} \cdot \mathrm{C}_{2} \cdot \mathrm{C}_{3}$ ，を新しく加え，それぞれの平均 等価直径亡樋巾との比を求め, この比と積込重量単位当 りの流れ抵抗とを $H / B=1$ の場合について例示すると第 15図となるので, 表面のひつかかり状態と形状が相似し 粒度曲線の形も似ている異径の粒体群についても，既掲 の実験結果の示すところを延長して適用出来るもの之考
える。

ただし粒体中に大塊がありチェーンに挾まれて実際上 チェーン搔き羽根の一部を構成するような場合は，この 搔出乙作用が極めて強く影響して流れを良好とするの で，以上の結果をそのます機械的に適用することは出来 ない。

\section{7. 結言}

以上を要約するとつぎの通りである。

（1）極めて短かい樋を使つてもコンベャー樋の中の 粒体の流れ性能についての究明が出来るので，その設計 や使用条件の検討に簡便でめる。

(2) Ц型の熥について粒体の流れ模様と側壁圧とを 調べて流れ抵抗との関連を求め，この流れ抵抗（硧底摩 擦によるものを含まない）が側壁への粒体静圧に上るも のと，粒体の相互滑りによるものとの合成であるとし，

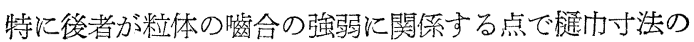
関数であり，チェーンに乗る崩壊角によつて境される山 形堆積部の安定一ししたがつてチェーンの搔出し作用の 伝達の強弱に関連する点でチェーン構造の関数であり， 粒体の相互流れ速度が大きく違う程大きな值をとり, 流 れ抵抗の主要部分を占めるものと推察した。著者の例示 では両者の比は最大值で 1.3〜2 倍となつた。

（3）異径であつてる内外摩擦に関係する表面の性質 や形状が相似し，その粒度配合の頻度曲線もよく似てい る粒体群の龊合の強弱は, 平均等価直径と樋巾との比で 代示される。

（4）コンベヤ一樋とチェーソの設計にあたつては, その使用条件と運搬粒体を考慮して，上述の滑り抵抗を 消隇させるように留意すべきである。

な扣装置 I を利用すると流れの機構を解析する資料が 求められて便利であるが，紙面の都合上 1 例の外は省略 した。

\section{参考 交 献}

1) 藮部: 構造力学 $\mathrm{V}$, 昭和 29 年 $130 \sim 137$ 頁

2）青山・下村：日本鉱業会誌 59 巻 609 号 162 頁.

3) J. Tayler: T. I. Min. Eng. Vol. 59 p. 168.

4) Cam: Earth Pressure Walls and Bius. 1916 p. 209.

5) 鸜部：構造力学V. 昭和 29 年 $112 \sim 11$ 頁.

6) 加藤：日本鉱業会誌 51 巻 603 号 419 頁.

7) A.'Vierling - M. Lamm : V. D. I. Bd. 83 S. $499 \sim 502$

8) Зенков Р. Л.: Теория и расчег конвейеров с ПерфорировАнной лентой, Сборник «Новые конструкции конвеиеров $\gg$. Книга 3, ВНИПТМАШ. 1949.

9) G. Hanffstengel: Die Förderung von Masseugüteu. 1921 Bd I S. 70. 